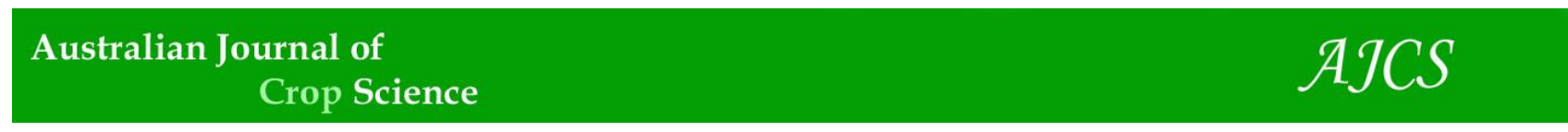

AJCS 13(09):1503-1510 (2019)

ISSN:1835-2707

doi: 10.21475/ajcs.19.13.09.p1727

\title{
Operational cost of mechanized harvesting of first-crop coffee
}

\author{
Felipe Santinato ${ }^{1^{*}}$, Carlos Diego da Silva ${ }^{2}$, Rouverson Pereira da Silva ${ }^{3}$, Antônio Tassio Silva Ormond ${ }^{4}$, \\ Victor Afonso Reis Gonçalves ${ }^{5}$, Roberto Santinato ${ }^{6}$
}

\author{
${ }^{1}$ Agronomic Institute of Campinas, IAC, Avenida Barão de Itapura, 1,481 Botafogo, Campinas, São Paulo, Brazil \\ 2Department of Rural Engineering., UNESP State University of São Paulo "Júlio de Mesquita Filho", Jaboticabal \\ Campus, Path of Access Prof. Paulo Donato Castellane, s / n, 14884-900, Jaboticabal, São Paulo, Brazil \\ ${ }^{3}$ Federal University of Viçosa, UFV, Campus Rio Paranaíba, Highway MG-230, km 7, 38810-000, Rio Paranaíba, Minas \\ Gerais, Brazil \\ ${ }^{4}$ Department of Rural Engineering, UNESP Universidade Estadual Paulista "Júlio de Mesquita Filho", Jaboticabal \\ Campus, Path of Access Prof. Paulo Donato Castellane, s / n, 14884-900, Jaboticabal, São Paulo, Brazil \\ ${ }^{5}$ Federal University of Viçosa, UFV, Campus Rio Paranaíba, Highway MG-230, km 7, 38810-000, Rio Paranaíba, Minas \\ Gerais, Brazil
}

${ }^{6}$ MAPA/Procafé, Street of Margaridas, 783 - Chácara Primavera - CEP: 13087-450 Campinas, São Paulo, Brazil

*Corresponding author: rsantinatocafeicultura@hotmail.com

\begin{abstract}
The use of adapted harvesters for harvesting first-crop coffee requires a lower cost and exhibits a higher efficiency than manual harvesting. In view of this, the present study aimed to analyze the operational cost of mechanized harvesting of first-crop coffee. The experiment was conducted in a factorial scheme $(2 \times 3)+1$ and outlined in randomized blocks with five replications. There were seven treatments: two automotive harvesters (conventional and adapted) with times of operations for each harvester (1, 2 and 3 time operations) and manual harvesting. We tested these treatments in a young coffee crop planted in Catalão, GO, irrigated by Pivot, with $1.5 \mathrm{~m}$ of height. We measured the lost coffee, coffee harvest, remaining coffee before the operation to obtain efficient parameters and with the prices of the operations and the costs of the treatments. When operated once and three times, the adapted harvester required a lower transfer cost than the conventional harvester. Moreover, the adapted harvester showed no difference in cost between each operation. The cost reduction by mechanized harvesting varied from 23.96 to $59.9 \%$, depending on the frequency of the mechanized operations. In conclusion, it is efficient to harvest the young coffee with the adapted harvesters reducing the cost of coffee harvesting.
\end{abstract}

Keywords: adapted harvester, costs, coffee.

Introduction

Usually, the first-crop coffee is harvested manually. Additionally, it is thought that because it is more fragile than adult crops, it can be severely damaged by the mechanized harvesting technique. Moreover, the fruits that are close to the coffee trunk and to the low insertion height of the basal plagiotropic branch are difficult to harvest using a mechanized harvester because of their positions in the plant. Thus, in order to harvest these fruits, the harvester's stems need to be closer together, which increases the damage to the plants. The plagiotropic branches are not harvested and often broken because they are too close to the soil and placed below the harvester (Matiello et al., 2010). The option to make adaptations to the harvesters has allowed this type of plant to be harvested, overcoming the aforementioned problem. The main adaptations made by some companies include replacing the support of the mats ("troughs") for greater retraction, increasing the width of the mats and replacing their holes, drawing together the cylinders of the feet, and altering the arrangement of the rods. Normally, adapted harvesters are rented for harvesting outsourced crops. Santinato et al. (2014) reported that this type of harvester increased the amount of coffee harvest from 61 to $114 \%$ more than conventional harvesters, supporting the need for adapted harvesters in coffee harvesting. The efficiency of adapted harvesters can be even higher if used in more than one operation (Santinato et al., 2015a) and if further changes are made for selective coffeeharvesting (Silva et al., 2013). Mechanized harvesting is a method that reduces the cost of the harvesting process. It is approximately $50 \%$ more economically efficient than manual harvesting (Silva et al., 2003; Oliveira et al., 2007). For harvesting crops with a productivity of approximately 30 to 35 bags ha-1 $^{-1}$ coffee, mechanized harvesting costs 41 to 50 $\%$ lower than manual harvesting when using harvesters in two operations (Silva et al., 2003; Silva et al., 2004).

The mechanization of the coffee crops, the development of the culture and the sustainable coffee, the business depends 
of the studies that improve the real benefits of the completely substation of the manual labor for the harvesters. In view of this, the present study aimed to analyze the cost of mechanized harvesting of first-crop coffee using owned or rented (adapted) harvesters in repeated operations.

\section{Result and discussion}

The hourly costs of the coffee-harvesting operation were US\$ $51.41 \mathrm{~h}^{-1}$ and US\$ $66.57 \mathrm{~h}^{-1}$ when using owned and rented harvesters, respectively (Table 1 ). The main factors that affect the hourly costs were: maintenance cost, fuel cost, and depreciation cost, which accounted for 36.6, 29.3, and $23.4 \%$ of the total hourly cost, respectively. This finding indicated the need for preventive maintenance measures to minimize costly machine-repairs (Mialhe, 1974).

The costs of harvesting using owned harvester in one, two, and three operations were US\$154.25 ha-1, US\$236.5 ha-1, and US\$ $1354.93 \mathrm{ha}^{-1}$, respectively (Table 1 ). On the other hand, harvesting using rented harvester in one, two, and three operations cost US\$ $199.70 \mathrm{ha}^{-1}, 306.20 \mathrm{ha}^{-1}$, and 459.32 ha $^{-1}$, respectively. In other words, the cost per hectare of mechanized harvesting using rented harvester was $29 \%$ higher than using owned harvester. However, both harvesters performed the operation with efficiency proportional to the final cost, as discussed below.

The hourly operation costs of the two harvesters, which involved the harvesting of fallen coffee, were US\$17.94 $\mathrm{h}^{-1}$ and US\$ $20.28 \mathrm{~h}^{-1}$ for the blowing/dressing and collection, respectively (Table 2 ). In addition to the two operations, the hourly cost was US\$38.22 $\mathrm{h}^{-1}$. The cost per hectare of the blowing/dressing and the collection were US\$ $43.05 \mathrm{ha}^{-1}$ and US\$ $97.36 \mathrm{ha}^{-1}$, respectively. Thus, the total cost of the mechanized collection was US\$ $140.42 \mathrm{ha}^{-1}$.

The data in Table 3 were used to carry out the calculations of the cost of fallen-coffee collection via sweeping and mechanized collection, as well as the cost of manual transfer. The discussion of these data is not included in this article.

There was no difference in fallen-coffee collection cost between the adapted and conventional harvesters when used in one and two operations (Table 4). This was due to the small difference in the quantities of fallen-coffee collected by the harvesters. However, when used in three operations, the adapted harvester required a higher cost of collection (US\$ $150.05 \mathrm{ha}^{-1}$ ) than the conventional harvester because the amount of fallen-coffee it collected was higher (4.5 or more bags of coffee $\mathrm{ha}^{-1}$ ) than that of the conventional harvester.

The cost of manual collection of ground coffee accounted for a large part of the total cost, often exceeding the cost of mechanized harvesting operation (Santinato et al., 2015b). Therefore, it is necessary to opt for strategies that minimize the amount of fruit or grain fallen in the mechanized harvesting of coffee or cereals, respectively.

When operated once and three times, the adapted harvester required a lower manual transfer cost than the conventional harvester (Table 5). This was because when operated in one and three operations, the adapted harvester obtained melted coffee with a greater efficiency than the conventional harvester, allowing a smaller amount of remaining coffee the plants. However, when operated twice, there was no difference in costs between the two harvesters.

Harvesting in two and three operations, regardless of the harvester used, had a lower manual transfer costs than in two operations (Table 5). However, the lowest cost was obtained by using the adapted harvester in three operations, as the remaining 6.8 bags of ben coffee ha-1 treatment did not eliminate the need for manual transfer.

A difference in costs between the harvesters occurred only when the harvesters were operated once, in which the adapted harvester required a lower extra cost than the conventional harvester (Table 6). This was due to the high quantity of remnant coffee, which consequently generated much higher manual transfer cost.

All mechanized harvesting methods required lower costs than the manual harvesting (Table 7). The mechanized harvesting was 23.96 to $44.56 \%$ more economically efficient than the manual harvesting. The values varied substantially because six types of crops were studied in the present study. Our current findings served as evidence of the need for mechanized harvesting operation, in consistence with those of Lanna and Reis (2012).

When operated only once, the adapted harvester was more economically viable than the conventional harvester, saving US\$ 315.55 ha $^{-1}$. Even with the hourly cost of the adapted (leased) harvester being $29 \%$ more onerous, the benefits provided by its adaptations reduced the operational cost in detriment of higher harvest efficiency. The final cost saving was $30.3 \%$. However, when operated more than once, there was no difference in cost between the harvesters. This is attributed to the expansion of outsourced harvester market in Brazil (Ortega et al., 2009).

In option 2, the manual collection of ground coffee is replaced by the mechanized collection. Thus, the extra cost of the operations was changed (Table 8). It was verified that when operated once and twice, the adapted harvester required lower extra costs than the conventional harvester. Fact occurred only for an operation, in the previous option. In this option, the adapted harvester was less costly than the conventional harvester when operated one, two, and three times in the same harvest (Table 9). The cost reduction was $37.9,10.5$, and $37.9 \%$, for one, two, and three operations, respectively. This finding indicated the need for replacing the manual collection of ground coffee with the mechanized collection. This substitution is widely performed in the Cerrado Region of Brazil, which has a high index of mechanization, and it should be expanded to all areas of Brazil where mechanization is possible (Tavares et al., 2015). For the adapted harvester, there was no difference in cost between the number of operations because even if the operational cost of the increased (increased hour of machine operation), the increase in harvesting efficiency and the consequent reduction of the need for manual transfer contributed in keeping the cost stable (Table 9). The increase in harvesting efficiency due to the increase in mechanized 
Table 1. Composition of the operational cost of mechanized harvesting of the plant coffee.

\begin{tabular}{|c|c|c|c|c|}
\hline \multirow[t]{2}{*}{ Item } & \multicolumn{4}{|c|}{ Composition of cost } \\
\hline & Harvester & Tractor & Trailer & Total cost \\
\hline & \multicolumn{4}{|c|}{ - } \\
\hline Depreciation (Dp) & 9.48 & 2.20 & 0.36 & 12.04 \\
\hline Jurus on capital (J) & 0.23 & 0.05 & 0.008 & 0.29 \\
\hline Insurance and shelter rate (IS) & 0.48 & 0.07 & 0.01 & 0.49 \\
\hline Total (CF) & 10.21 & 2.32 & 0.38 & 10.6 \\
\hline Fuel cost (FC) & $7.07(4.39)^{*}$ & 7.97 & - & 15.05 \\
\hline Cost of lubricants and greases (CLG) & 0.17 & 0.17 & - & 0.35 \\
\hline Hydraulic Oil Cost (HOC) & 0.54 & 0.09 & - & 0.63 \\
\hline Cost with maintenance (CM) & 16.26 & 2.43 & 0.12 & 18.82 \\
\hline Operational staff cost (OSC) & 2.97 & 2.97 & - & 5.95 \\
\hline Total (CV) & 27.02 & 13.66 & 0.12 & 40.81 \\
\hline Total cost $\left(\mathrm{US} \$ \mathrm{~h}^{-1}\right)$ & 38.15 & 15.98 & 0.5 & 51.41 \\
\hline
\end{tabular}

${ }^{*}$ The values referring to conventional and adapted harvesters, respectively.

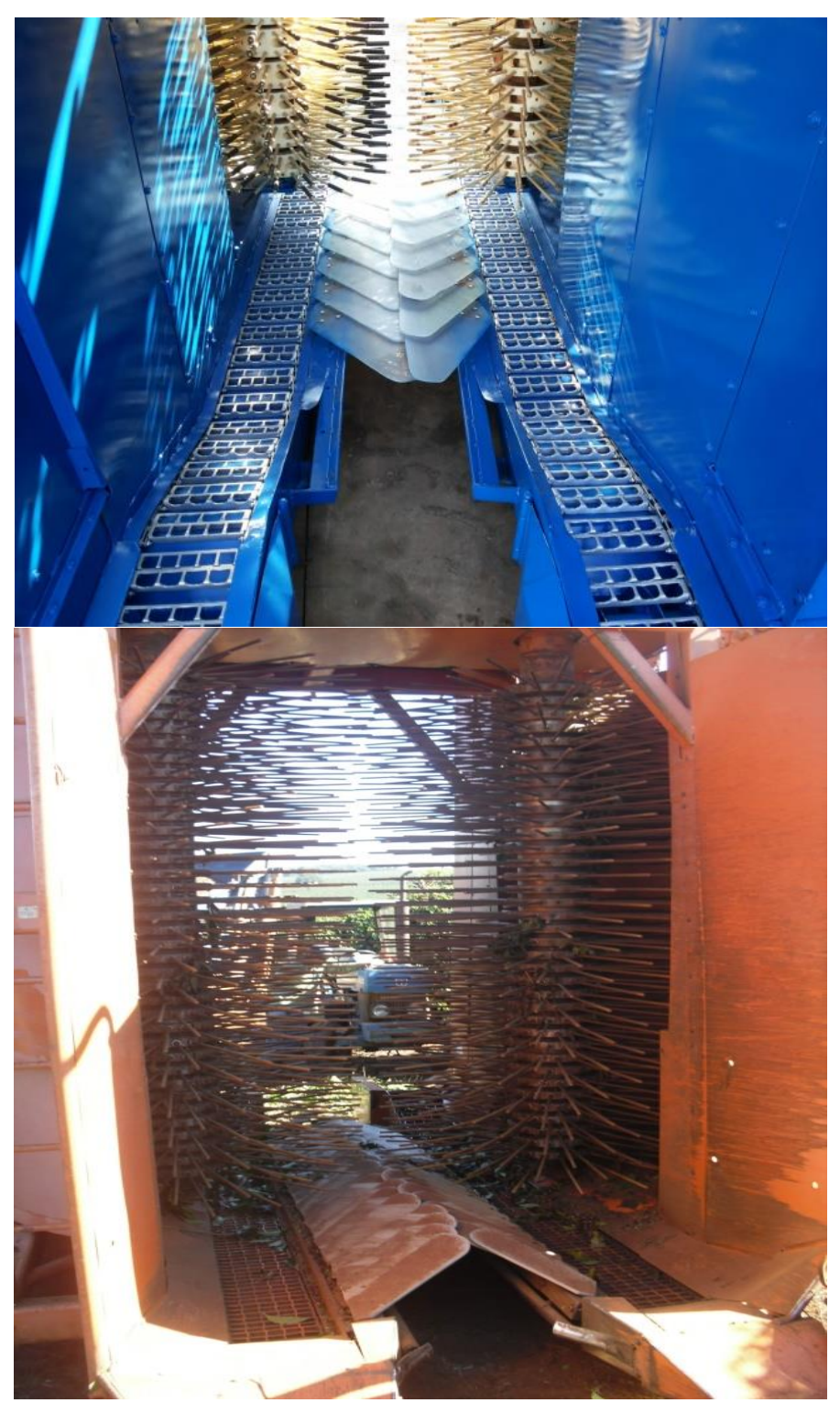

Fig 1. A adapted and conventional harvesters. 
Tabela 2. Composition of the operational cost of ground coffee mechanized harvesting.

\begin{tabular}{|c|c|c|c|c|}
\hline \multirow[t]{2}{*}{ Item } & \multicolumn{4}{|c|}{ Composition of cost } \\
\hline & Recolder & Cost 1 & Blower / trowel & Cost 2 \\
\hline & \multicolumn{4}{|c|}{ 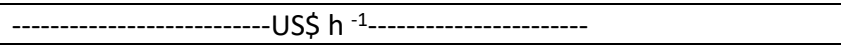 } \\
\hline Depreciation (Dp) & 2.18 & 4.37 & 0.89 & 3.08 \\
\hline Jurus on capital (J) & 0.10 & 0.15 & 0.02 & 0.08 \\
\hline Insurance and shelter rate (IS) & 0.9 & 0.16 & 0.02 & 0.10 \\
\hline Total (CF) & 2.37 & 4.69 & 0.95 & 3.27 \\
\hline Fuel cost (FC) & - & 7.97 & - & 7.97 \\
\hline Cost of lubricants and greases (CLG) & - & 0.17 & - & 0.17 \\
\hline Hydraulic Oil Cost (HOC) & 0.22 & 0.31 & - & 0.09 \\
\hline Cost with maintenance (CM) & 3.11 & 5.55 & 1.00 & 3.44 \\
\hline Operational staff cost (OSC) & - & 2.97 & - & 2.97 \\
\hline Total (CV) & 3.33 & 17.00 & 1.00 & 14.66 \\
\hline Total cost (US \$ $\mathrm{h}^{-1}$ ) & 5.71 & 20.28 & 1.95 & 17.94 \\
\hline
\end{tabular}

* To calculate the total cost of operations, the hourly cost of the tractors involved in the operations was added.

** Cost 1 = Cost of collection; Cost 2 = Cost of blowing.

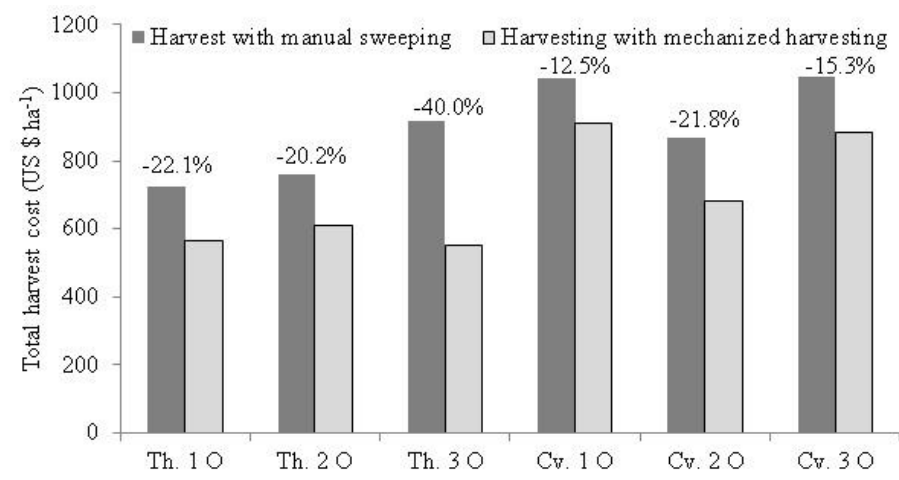

Fig 2. Comparison between mechanized harvesting with manual sweeping and mechanized harvesting. In what: Th. = Tail harvester; $\mathrm{Cv} .=$ Conventional harvester; $\mathrm{O}=$ Operations US $\left.\$ \mathrm{ha}^{-1}\right)$.

Table 3. Amount of coffee dropped and remaining as a function of the treatments studied.

\begin{tabular}{|c|c|c|c|c|c|c|}
\hline \multirow{4}{*}{ Harvester } & \multicolumn{6}{|c|}{ Number of harvester operations } \\
\hline & \multicolumn{2}{|r|}{1} & \multirow{2}{*}{\multicolumn{2}{|c|}{$\frac{2}{\text { nt of coffee (bean. ha-1 coffe }}$}} & \multicolumn{2}{|c|}{3} \\
\hline & \multicolumn{4}{|c|}{ Amount of coffee (bean. ha-1 coffee bags) } & & \\
\hline & Fallen & Remaining & Fallen & Remaining & Fallen & Remaining \\
\hline Adapted & $9.4 \mathrm{aA}$ & $15.3 \mathrm{aB}$ & $10.1 \mathrm{aA}$ & $11.3 \mathrm{aAB}$ & $13.5 \mathrm{aA}$ & $6.8 \mathrm{aA}$ \\
\hline Conventional & $8,1 \mathrm{aA}$ & $34.2 \mathrm{bB}$ & $9.9 \mathrm{aA}$ & $13.9 \mathrm{aA}$ & $9.0 \mathrm{aA}$ & $17.1 \mathrm{bA}$ \\
\hline \multicolumn{3}{|c|}{ Decreased coffee yield $=27.39$} & \multicolumn{4}{|c|}{ CV remaining coffee $=24.08$} \\
\hline
\end{tabular}

Table 4. Sweeping costs of coffee from the ground as a function of the quantity of coffee dropped from mechanized coffee harvesting.

\begin{tabular}{llll}
\hline \multirow{2}{*}{ Treatments } & \multicolumn{3}{c}{ Cost of sweeping ground coffee $\left(\mathrm{R} \$\right.$ ha $^{-1}$ ) } \\
\cline { 2 - 4 } & \multicolumn{3}{c}{ Number of harvester operations } \\
\cline { 2 - 4 } & $1162.70 \mathrm{aA}$ & 2 & $1661.04 \mathrm{bB}$ \\
\hline Adapted & $996.64 \mathrm{aA}$ & $1245.16 \mathrm{aA}$ & $1107.36 \mathrm{aA}$ \\
Conventional & 27.48 & $1218.10 \mathrm{aA}$ & \\
\hline $\mathrm{CV}(\%)$ & ${ }^{*}$ Means followed by the same lowercase letters in the columns and upper case in the lines, do not differ from each other by the Tukey test, at 5\% probability.
\end{tabular}

Table 5. Cost of the manual transfer as a function of the quantity of coffee dropped from the mechanized harvest of the coffee.

Treatments

\begin{tabular}{llll} 
& \multicolumn{4}{c}{} & 2 & 3 \\
\cline { 2 - 4 } Adapted & $941.25 \mathrm{aB}$ & $692.10 \mathrm{aAB}$ & $415.26 \mathrm{aA}$ \\
Conventional & $2103.98 \mathrm{bB}$ & $858.20 \mathrm{aA}$ & $1051.99 \mathrm{bA}$ \\
\hline CV $(\%)$ & 24.14 & & \\
\hline *Means followed by the same lowercase letters in the columns and upper case in the lines, do not differ from each other by the Tukey test, at 5\% probability.
\end{tabular}


Table 6. Total extra costs (manual transfer and sweeping) as a function of the amount of coffee that has fallen due to mechanized coffee harvesting.

\begin{tabular}{|c|c|c|c|}
\hline \multirow{3}{*}{ Treatments } & \multicolumn{3}{|c|}{ Extra cost option $1\left(\mathrm{R} \$ \mathrm{ha}^{-1}\right)$} \\
\hline & \multicolumn{3}{|c|}{ Number of harvester operations } \\
\hline & 1 & 2 & 3 \\
\hline Adapted & $2104.00 \mathrm{aA}$ & 1937.26 aA & $2076.30 \mathrm{aA}$ \\
\hline Conventional & $3100.60 \mathrm{bB}$ & $2076.30 \mathrm{aA}$ & $2159.34 \mathrm{aA}$ \\
\hline CV (\%) & 20.01 & & \\
\hline
\end{tabular}

Table 7. Total cost of mechanized harvesting of first-crop coffee as a function of the quantity of coffee fallen from mechanized coffee harvesting.

\begin{tabular}{llll}
\hline \multirow{2}{*}{ Treatments } & \multicolumn{3}{c}{ Total cost option 1 (R\$ ha ${ }^{-1}$ ) } \\
\cline { 2 - 4 } & \multicolumn{3}{c}{ Number of harvester operations } \\
\hline Adapted & $2840.90 \mathrm{aA}$ & 2 & $3771.20 \mathrm{aA}$ \\
Conventional & $3669.80 \mathrm{bA}$ & $3067.20 \mathrm{aA}$ & $3469.00 \mathrm{aA}$ \\
Manual Harvesting & $5069.25 \mathrm{~b}$ & $2949.00 \mathrm{aA}$ & \\
\hline $\mathrm{CV}(\%)$ & 13.62 & & \\
\hline${ }^{*}$ Means followed by the same lowercase letters in the columns and upper case in the lines, do not differ from each other by the Tukey test, at 5\% probability.
\end{tabular}

Table 8. Total extra cost (manual transfer and collection of mechanized coffee) as a function of the amount of coffee that has fallen due to mechanized harvesting of the coffee.

\begin{tabular}{llll}
\hline \multirow{2}{*}{ Treatments } & \multicolumn{3}{c}{ Extra cost option 2 $\left(\$\right.$ ha $\left.^{-1}\right)$} \\
\cline { 2 - 4 } & 1 & 2 & 3 \\
\hline Adapted & $1459.42 \mathrm{aB}$ & $1210.28 \mathrm{aAB}$ & $933.40 \mathrm{aA}$ \\
Conventional & $2622.14 \mathrm{bB}$ & $1376.38 \mathrm{aA}$ & $1570.16 \mathrm{bA}$ \\
\hline $\mathrm{CV}(\%)$ & 15.96 & & \\
\hline${ }^{*}$ Means followed by the same lowercase letters in the columns and upper case in the lines, do not differ from each other by the Tukey test, at 5\% probability.
\end{tabular}

Table 9. Total cost of fully mechanized harvesting of first-crop coffee (with mechanized collection instead of manual sweeping) as a function of the quantity of coffee that has fallen due to mechanized harvesting of the coffee.

\begin{tabular}{llll}
\hline \multirow{2}{*}{ Treatments } & \multicolumn{3}{c}{ Total cost option 2 $\left(\$\right.$ ha $\left.^{-1}\right)$} \\
\cline { 2 - 4 } & 1 & 2 & 3 \\
\hline Adapted & $2196.30 \mathrm{aA}$ & $2340.20 \mathrm{aA}$ & $2628.30 \mathrm{aA}$ \\
Conventional & $3191.30 \mathrm{bB}$ & $2249.10 \mathrm{bA}$ & $2879.80 \mathrm{bB}$ \\
Manual Harvesting & & $5069.25 \mathrm{~b}$ & \\
\hline CV (\%) & 9.45 & & \\
\hline *Means followed by the same lowercase letters in the columns and upper case in the lines, do not differ from each other by the Tukey test, at 5\% probability.
\end{tabular}

operation number had already been verified by Santinato et al. (2015a). In contrast, the conventional harvester required the lowest cost when it was operated twice (Table 9). With one operation, despite requiring low hourly cost, it also required a high manual transfer cost. Moreover, with three operations, the hourly cost was very high and there was no increase in operational efficiency. In this option, the mechanized harvest was 33.73 to $59.9 \%$ more economically efficient than the manual harvest. These values corroborate those reported by Oliveira et al. (2007) and Santinato et al. (2015b). Table 9 shows the total cost of a fully mechanized harvesting of first-crop coffee (with mechanized collection instead of manual sweeping) as a function of the amount of fallen coffee. On average, all treatments showed a cost reduction of $21.97 \%$ by replacing manual sweeping with mechanized harvesting (Figure 1). The cost reduction varied from 12.5 to $40.0 \%$ because of the amount of coffee dropped in each treatment. This study provided evidence of the need for mechanization in all coffee harvesting operations. The mechanized areas in coffee crop has increasing and exceed 1.0 million ha in Brazil. Before areas with high slopes we cannot mechanized but in a recent research Santinato et al., (2016) show that is possible harvest with the harvesters up $30 \%$ of slopes. Santinato et al., (2015c) show to us that is possible harvest young coffees with less damage in the plants. Silva et al., (2015) have evidenced new technologies to increase the efficient of the harvesters. So, the evolution go to other mechanized operations like showed by Tavares et al., (2018). In other words the advancing of the mechanization in coffee was increasing and this study have the proposed to show the economic factors of the operations. Brazil is the biggest coffee grower in the world (CONAB, 2014) and has been the lower productive costs and the mechanization is the main 
cause of this (FAOSTAT, 2014). Other countries have been find alternatives to mechanize their farmers and this study present substantially datum to evidence these benefits and boost these.

\section{Materials and methods}

\section{Plant materials}

The study was conducted in the AgroFava Farm in the municipality of Catalão, GO, Brazil. The farm is located between $17^{\circ} 29^{\prime} 29.97^{\prime \prime}$ South Latitude and 47\%9'32.39" West Longitude in the Cerrado Goiano region. It has an average altitude of $955 \mathrm{~m}$ and Aw climate according to Köeppen's classification (1948).

The plantation was sown with irrigated coffee plants under the central pivot of the cultivar Catuaí

Vermelho IAC 144. The plants were sown in 2013, with spaces of $3.7 \mathrm{~m}$ between rows and $0.5 \mathrm{~m}$ between plants, as well as a population density of 5,405 plants ha ${ }^{-1}$. The crop was $1.57 \mathrm{~m}$ in height. The insertion height in the basal plagiotropic branches was $29.2 \mathrm{~cm}$. The crops have a productivity of 82.4 bags of ben coffee ha ${ }^{-1}$, with the percentages of fruits in the green, cherry, and dry stages of $44.4,47.1$, and $8.5 \%$, respectively.

\section{Treatments and experimental design}

The study consisted of seven treatments of plots in a factorial scheme $(2 \times 3)+1$ and outlined in randomized blocks with five replications, generating a total of 35 plots. Three treatments were harvested with a conventional automotive harvester in one, two, or three operations; three treatments were harvested with adapted harvesters in one, two, or three operations; and one treatment was harvested manually. The harvests have a series of differences between them. The conventional was projected to harvest big plants, with the most part of the fruits in the center and the top of the plant. Other difference is that in adult plants the fruits are present in the end of the branches. This kind of harvest cannot be operated near the ground because its parts are so big. To harvest the young coffee they adapted the harvest replacing these parts to another less thick allowing the operation near the ground. This is necessary because the young coffee has many branches near the ground and they could be damaged by the conventional harvest. The young coffee has the coffee beans near the trunk and the fruits are concentrated in the center of the plant. Because of this the harvest has stalks near between them. Some differences can see in the next Figure. The plots, composed of five plants, were spaced $20 \mathrm{~m}$ apart to provide enough time for the tractor to change gear, allowing the desired operational speed for each group and the stability of the required rotation.

For the automated harvesters, the operating speeds of the rods in one, two, and three operations were 1,$000 ; 1,300$; and $1,300 \mathrm{~m} \mathrm{~h}^{-1}$, respectively, and the vibrations were 1,000; 800; and $700 \mathrm{rpm}$, respectively. Thus, the operations were conducted for $3.0,4.6$, and $6.9 \mathrm{~h} \mathrm{ha}^{-1}$, with an operational field capacity of $0.33,0.22$, and $0.14 \mathrm{ha}^{-1}$ for operations one, two, and three, respectively. In all calculations, the operating time was lengthened by $20 \%$ to accommodate the time spent for maneuvering in the carriers and for interruptions (Silva et al., 2003). The coffee harvested by the harvesters was transferred to a Cargo 5,000 cart, which is equipped with two axles and a storage capacity of $5.18 \mathrm{~m}^{3}$. The cart was driven by a $4 \times 2$ TDA tractor, with a nominal power of $64.9 \mathrm{hp}$ at 2,160 rpm, and a TDP tractor at $540 \mathrm{rpm}$. Both tractors always travel in the same direction during operation. The same tractors were also used for blowing/dressing and collecting coffee from the ground.

\section{Conduction of study and evaluations}

Firstly, crop productivity was determined through the manual melting of all pending load from the five plots of the manual harvest group. "Spoil" cloths of approximately $2.5 \times$ $2.0 \mathrm{~m}$ were placed under the plant canopy on both sides of the coffee line so that one overlapped the other. Afterward, the fruits were crushed from the feet. The volume of the coffee harvest was weighed and a $2.0 \mathrm{~L}$ aliquot was withdrawn for the determination of the maturation stage. Next, the fruits at the green, cherry, and dry stages were separated. To evaluate aspects inherent to the mechanized harvesting (fallen, remaining, harvested, and melted coffee), pieces of cloth were placed under the canopy of five plants following Cassia et al., (2016). Next, the harvester was operated. After it passed through, the coffee that had broken off the branches and fallen into the cloth was collected and weighed. This coffee was called the fallen coffee. After being cleaned and wiped, the pieces of cloth were placed again under the feet of the plants and the fruits that remained in the branches were melted and measured, as previously described. This coffee was called the remaining coffee. Harvested coffee was obtained via subtraction of the initial productivity by the remaining and fallen coffee.

The total operational cost of mechanized harvesting was analyzed separately for each machine used in the harvesting process, namely self-propelled harvesters, a cart, two tractors, a blower/tiller, and a picker. The cost was expressed in reals per effective working hour $\left(R \$ h^{-1}\right)$. The hourly cost was calculated by adding the fixed and variable costs, as detailed below. The fixed costs were as follows:

\section{Cost of depreciation (Dp)}

The depreciation cost was calculated using the linear depreciation method (Equation 1).

$D p=\frac{\mathrm{Vi}-\mathrm{Vr}}{\mathrm{Lu}} \quad$ Equation 01

On what:

$D p=$ linear depreciation of the machine (US\$ $h^{-1}$ )

$\mathrm{Vi}=$ initial value of the machine (US\$)

$\mathrm{Vr}=$ residual value (US\$)

Lu $=$ useful life $(\mathrm{h})$

Based on the average value of the region's resales, the purchase value of the harvester was US\$162.601,62 and the residual value after $10,000 \mathrm{~h}$ of use was US\$ $67.750,67$. For the collector, we used an initial value of US\$31.165,31 and a final value of US\$24.390,24. The initial values of the two tractors, cart, and blower/squirrel were US\$24.390,24 US\$ $4.065,04$ and US\$10.027,10 respectively. The residual value was $10 \%$ of the initial value (Mialhe, 1974). 


\section{Cost of interest on tied capital (J).}

The cost of interest on the tied capital corresponds to the opportunity cost and represents the value that the producer fails to earn by investing in coffee instead of in another source of income. It was calculated based on the $5 \%$ interest rate provided by the farms (Equation 2).

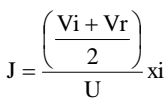

Equation 02

On what:

$\mathrm{J}=$ interest cost (US\$)

$\mathrm{Vi}=$ initial value of the machine (US\$)

$\mathrm{Vr}=$ residual value (US\$)

$\mathrm{U}=$ useful life $(\mathrm{h})$

$\mathrm{i}=$ interest rate $(\%)$

\section{Cost of insurance and housing tax (SA)}

In this study, we adopted the $3 \%$ insurance and shelter rate used by Banco Rural and the main insurers of the state of Minas Gerais (Equation 3).

The variable costs were as follows:

Cost of fuel (CC)

$$
\mathrm{SI}=\frac{\mathrm{Vi}}{\mathrm{L}} \mathrm{xSR}
$$

Equation 03

On what:

$\mathrm{SI}=$ cost of insurance and shelter (US\$)

$\mathrm{Vi}=$ initial value (US\$)

$\mathrm{L}=$ lifetime $(\mathrm{h})$

$\mathrm{Sr}=$ rate on shelter $(\%)$

In general, the cost of fuel is mostly used for calculating the operational costs. The cost of fuel was equal to the average fuel consumption of the farm during operations multiplied by the average price of diesel sold in the region (US\$3.00 $\mathrm{L}^{-}$ 1). We calculated an average consumption of 5.4 and $8.7 \mathrm{~L} \mathrm{~h}^{-}$ 1 for adapted and conventional harvesters, respectively.

The cost of fuel for the tractor that drew the cart was calculated according to the power take-off of the tractor (ASAE, 1998) (Equation 4).

\section{$\mathrm{Cf}=0.151 \times \mathrm{MpaoxVf} \quad$ Equation 04}

On what:

$\mathrm{Cf}=$ fuel cost $\left(\right.$ US\$ $\left.\mathrm{h}^{-1}\right)$

$\mathrm{Mpao}=$ maximum power available at the power outlet (cv) $V f=$ fuel value $\left(U S \$ L^{-1}\right)$

\section{Cost of lubricants and greases (CLG)}

The cost related to the consumption of lubricating oil was determined according to the calculation described by ASAE (1998) (Equation 5).

$$
\begin{aligned}
& \mathrm{Cl}=\left(4.3 \times 10^{-4}\right)(\mathrm{P}+0.02169) \\
& \text { On what: } \\
& \mathrm{Cl}=\text { cost with lubricants }\left(\mathrm{US} \$ \mathrm{~h}^{-1}\right) \\
& \mathrm{P}=\text { Rated motor power, }(\mathrm{cv})
\end{aligned}
$$

The cost of grease was estimated by assuming a grease consumption of $0.5 \mathrm{~kg}$ every ten working hours for each machine, i.e. $0.05 \mathrm{~kg}$ of grease $\mathrm{h}^{-1}$. Thus, we determined a cost value of US\$3.38 $\mathrm{kg}^{-1}$.

\section{Hydraulic oil cost (COH)}

The hydraulic oil cost was determined according to the consumption and value of the filter (Equation 6).

$\mathrm{CWH}=\mathrm{Vx} \frac{\mathrm{CT}}{\mathrm{Oct}}+\frac{\mathrm{Fv}}{\mathrm{Ttf}} \quad$ Equation 06

On what:

$\mathrm{CWH}=$ cost with hydraulic oil (US\$ $\left.\mathrm{h}^{-1}\right)$

$\mathrm{V}=$ value of hydraulic oil (US\$ $\left.\mathrm{L}^{-1}\right)$

$\mathrm{CT}=$ tank capacity $(\mathrm{L})$

Oct = oil change time $(\mathrm{h})$

$\mathrm{Fv}=$ filter value (US\$)

Through market research, we determined that the values of the hydraulic oil, filter of the harvester, and filter of the tractor are US\$ 2,43 L-1, US\$ 40,65, and US\$ 18,97, respectively. The storage capacities of the harvester and tractor are $250.0 \mathrm{~L}$ and $40.0 \mathrm{~L}$, respectively. The time required effecting the oil and filter changes of both machines is $1,200 \mathrm{~h}$.

Cost with maintenance (CM)

The cost of maintenance includes preventive and corrective maintenance, as well as the labor required to perform the maintenance (ASAE, 1998) (Equation 7).

$\mathrm{CM}=\frac{\mathrm{MR}}{\mathrm{L}} \times \mathrm{Iv}$

Equation 07

On what:

$\mathrm{CM}=$ maintenance cost (US $\left.\$ \mathrm{~h}^{-1}\right)$;

$M R=$ maintenance rate $(\%)$;

$\mathrm{L}=$ lifetime $(\mathrm{h})$

Iv = initial value (US\$)

The maintenance rate varied from 10 to $30 \%$ and 70 to 100 $\%$ for equipment and machines, respectively (Mialhe, 1974). In the present study, we adopted maintenance rates of 100 $\%$ for the harvester and picker, $70 \%$ for the tractor and blower/drawer, and $30 \%$ for the cart.

\section{Operational staff cost (COM)}

To determine the cost of operating personnel, we analyzed the direct salary expenses plus benefits and social-security charges. The operator's salary was US\$ 386.92 plus $53.93 \%$ benefits and other expenses (Dieese, 2014), accumulated to a total of US\$ 595.59. Twenty-five work days and eight work hours each day were accounted for. Therefore, the cost of operational staff per work hour was US\$2.97 $\mathrm{h}^{-1}$.

In addition to the hourly cost, we calculated the costs of manual collection (sweeping) and the manual transfers of each mechanized harvesting method. The cost of sweeping was calculated by multiplying the amount of coffee dropped by the amount paid for the operation (US\$ 2.71 per amount of fallen coffee plus $53.93 \%$ of charges). The cost of manual transfer was calculated by multiplying the amount of the remaining coffee to US\$ 1.35 plus $53.93 \%$ of charges. Thus, the total cost of mechanized harvesting was calculated for the option to purchase all the machinery.

In order to calculate the cost of harvesting using an adapted harvester (T1 to T3), the hourly cost was replaced with US\$ 
$54.20 \mathrm{~h}^{-1}$ (rental price taken from the outsourcing companies), adding up to the fuel costs and the fixed and variable costs of tractors and trailers, which accumulated to a total of US\$ $66.57 \mathrm{~h}^{-1}$.

On the other hand, the cost of manual harvesting was calculated by multiplying the initial coffee quantity with the price paid per amount of coffee plus taxes. We used a value of US\$ 1.35 per amount of coffee for the high and intermediate load crops, respectively. This value is the common price paid in the region.

A secondary analysis was performed, in which manual sweeping was replaced by mechanized collection. This operation required 2.4 and $4.8 \mathrm{~h} \mathrm{ha}^{-1}$ of blower/squeegee and pickup equipment, respectively. This operation was performed because studies, such as that by Santinato et al. (2015b), showed that in certain cases, manual sweeping requires the highest cost among the entire harvesting operation.

Thus, we compared sweeping cost, manual transfer cost, extra cost 1 (sweeping plus transfer), extra cost 2 (collection plus loan), and the total costs of options 1 and 2 .

The data were analyzed using the analysis of variance and the Tukey test, both at $5 \%$ probability. All analyses were performed using the statistical program SISVAR version 5.3 (Ferreira, 2011).

\section{Conclusion}

The benefit to use the mechanized harvest instead of the manual is remarkable. The cost was reduced up to 24 to $60 \%$, depends on the treatment, the time was less, and these contributed to sustainable of coffee agrobusiness. This research validated the technique of the adapted harvesters in the young coffee crops using more than one operation with less damage, and increasing efficiency in the operation. With the correct settings in the harvest it's possible eliminated all the picking coffee by the hand.

\section{References}

American Society of Agricultural Engineerig (1998) ASAE Standards. St. Joseph, Agricultural management data ASAE D497.4. 360-367.

Cassia MT, Silva RP, Santinato F, Compagnon AM, Filho AC (2016) Effect of planting axles, sunligth faces and rod vibration frequencies in the mechanized coffee harvesting. Afr J Agric Res. 11: 391-399.

Conab (2014) Harvest 2001 to 2014: Historical series. http://www.conab.gov.br/conteudos.php?a $=1252 \& \mathrm{t}=2$ (accessed 8 Sept. 2014). Conselho Nacional de Abastecimento, Brasilia, DF, Brazil.

Dieese (2014) Encargos sociais no Brasil. Pesquisa Dieese. 12: 36.

FAOSTAT (2014) Trade: Crops and livestock products. Food and Agricultura Organization of the United Nations, Rome, Italy. http://faostat.fao.org/(accessed 9 Sept.2014)

Ferreira DF (2011) Sisvar: a computer statistical analysis system. Ciência e Agrotecnologia. 35 (6): 1039-1042.
Köeppen W (1948) Climatologia: con um estúdio de los climas de la Tierra. México: Fondo de Cultura Economica. 478.

Lanna GBM, Reis PR (2012) Influência da mecanização da colheita na viabilidade econonômico-financeira da cafeicultura no sul de Minas Gerais. Coffee Science. 7 (2): 110-121.

Matiello JB, Santinato R, Garcia AWR, Almeida SRA, Fernandes DR (2010) Cultura do Café no Brasil, Manual de Recomendações. Rio de Janeiro e Varginha: Fundação Prócafé, 542.

Mialhe LG (1974) Manual de mecanização agrícola. São Paulo: Agronômica Ceres, 297.

Oliveira E, Silva FM, Salvador N, Souza ZM, Chalfoun SM, Figueiredo CAP (2007) Custos operacionais da colheita mecanizada do cafeeiro. Pesquisa Agropecuária Brasileira. 42 (6): 827-31.

Ortega AC, Jesus CM, Mouro MC (2009) Mecanização e emprego na cafeicultura do cerrado mineiro. Revista ABET. 8 (2): 58-82.

Santinato F, Silva RP, Silva CD, Ruas RAA, Santinato R (2014) Desempenho operacional de colhedoras de café em primeira safra. In: CONGRESSO BRASILEIRO DE PESQUISAS CAFEEIRAS, 40, Serra Negra. Anais... Serra Negra: MAPA/PROCAFÉ, p.126-127.

Santinato F, Ruas RAA, Silva RP, Carvalho Filho A, Santinato R (2015a) Número de operações mecanizadas na colheita do café. Ciência Rural. 45 (10): 1809-1814.

Santinato $F$, Ruas RAA, Filho AC, Silva RP, Santinato $R$ (2015b) Análise econômica da colheita mecanizada do café utilizando repetidas operações da colhedora. Coffee Science. 10 (3): 402-411.

Santinato F, Silva CD, Silva RP, Ruas RAA, Fernandes ALT, Santinato R (2015c) Colheita mecanizada do café em lavouras de primeira safra. Revista Brasileira de Engenharia Agrícola e Ambiental. 19 (12): 1215-1219.

Santinato F, Silva RP, Silva VA, Silva CD, Tavares TO (2016) Mechanical harvesting of coffee in high slope. Revista Caatinga. 29 (3): 685-691.

Silva FM (2004). Colheita mecanizada e seletiva do café: cafeicultura empresarial: produtividade e qualidade. Lavras: Ufla/Faepe, 75.

Silva FM, Salvador N, Rodrigues RF, Tourino ES (2003) Avaliação da colheita do café totalmente mecanizada. Engenharia Agrícola, Jaboticabal. 23 (2): 309-15.

Silva FC, Silva FM, Silva AC, Barros MM, Palma MAZ (2013) Desempenho operacional da colheita mecanizada e seletiva do café em função da força de desprendimento dos frutos. Coffee Science. 8 (1): 53-60.

Silva FC, Silva FM, Alves MC, Ferraz GAS, Sales RS (2015) Efficiency of coffee mechanical and selective harvesting in different vibration during harvest time. Coffee Science, 10 (1): 56-64.

Tavares TO, Borba MAP, Oliveira BR, Silva RP, Voltarelli MA, Ormond ATS (2018) Effect of Soil managment practies on the sweeping operation during coffee harvest. Agronomy Journal. 110 (5):

Tavares TO, Santinato F, Silva RP, Voltarelli MA, Paixao CSS, Santinato R (2015) Qualidade do recolhimento mecanizado do café. Coffee Science. 10 (4): 455-463. 